\title{
THE MILES AND SNOW BUSINESS STRATEGY TYPOLOGY AND THE ADOPTION OF MANAGEMENT ACCOUNTING PRACTICES
}

\author{
Tuan Zainun Tuan Mat $^{1 *}$, Ammar Syafiq Subri ${ }^{2}$ \\ and Fadzlina Mohd Fahmi ${ }^{1}$ \\ ${ }^{1}$ Faculty of Accountancy, \\ Universiti Teknologi MARA, Malaysia \\ ${ }^{2}$ KPJ Perlis Specialist Hospital, Perlis, Malaysia
}

\begin{abstract}
Changes in the business environment requires that a company adopts a more adaptive strategy. A business strategy is not just about planning, but it needs to be supported with meaningful information. Management accounting complements a business strategy by providing crucial information, not just limited to cost efficiency, but customer satisfaction and quality management. However, the adoption of management accounting practices (MAPs) is believed to be influenced by strategy. Using the Miles and Snow (1978) business strategy typology model, this study examined the influence of business strategy on the adoption of MAPs, focusing on how the different types of business strategies used in organizations may influence the adoption of MAPs. Data was collected from manufacturing companies in Malaysia. The result showed that most Malaysian manufacturing companies utilized three major classifications of strategies, i.e., defender, prospector, analyzer, and only a few were classified as reactors. The result showed that the adoption level of both traditional and advanced MAPs is also high. Findings from this study indicated an influence of the defender and analyzer types towards adopting traditional MAPs, whereas the prospector type had influenced the adoption of advanced MAPs.
\end{abstract}

Keywords: management accounting practices, business strategy, defender, prospector, analyzer, reactor

\section{ARTICLE INFO}

\section{Article History:}

Received: 9 March 2021

Accepted: 19 July 2021

Published: 31 August 2021

* Corresponding Author: Tuan Zainun Tuan Mat. E-mail: tuanz693@uitm.edu.my 


\section{INTRODUCTION}

The role of management accounting has become more extensive compared to its function a decade ago. It became an integral part of an organization because management accounting provides valuable information in assisting decision-making to achieve organizational goals (Ilias, Razak, \& Yasoa', 2010). Furthermore, management accounting information is crucial because it helps managers make effective decisions (Tuanmat \& Smith, 2011). Previous researchers have agreed that management accounting is the critical determinant associated with better firm performance (Baines $\&$ Langfield-Smith, 2003). However, few researchers often questioned the ability of management accounting whether it could cope with the changes in the business environment apart from maintaining the accuracy and sufficiency of the information supplied to managers (Auzair et al., 2013). Thus, organizations must ensure that they adopt suitable management accounting practices (MAPs) which are capable to effectively provide accurate information for decision making in ensuring the success of an organization.

However, management accounting cannot be concluded as the only determinant of a firm's success because the practice depends on the business strategy adopted by the firm itself (Simon, 2008). Chenhall and LangfieldSmith (1998) stated that the relationship between the strategy of a firm and the adoption of MAPs had attracted the attention of many researchers in the last two decades. Business strategy plays a contingent variable in the study of how management accounting components such as the Management Control System (MCS) could improve an organization's performance (Chenhall \& Langfield-Smith, 1998b).

There is also evidence on the cross-linkages between management accounting techniques and a business strategy adopted by a firm (Kaplan $\&$ Norton, 1992). As the element of internal contingency, the strategy has become the explanatory variable in assessing the development of MAPs (Ahmad, 2012). Thus, it is essential to focus on how strategy utilization in the competing institutional pressures integrates into organizational practices (Laguecira, Kernc, \& Kharoubid, 2020). In the manufacturing sector, the business strategy induced is not an ordinary matter as it will shape a company. Regardless of the corporation's size, the optimal state of 
an organization can only be achieved when they can identify their missions and strategies from their characteristics and behaviors in operations (Miles \& Snow, 1978). Therefore, the selection of a suitable strategy will characterize the organization; but it will also mold its MAPs (Ramli \& Iskandar, 2014). A proper match between strategy and MAPs is crucial for the organization to perform better. Thus, this study investigated the influence of business strategy on MAPs among Malaysian manufacturing companies, specifically on how the different typologies of business strategies, proposed by Miles and Snow (1978), influence the adoption of MAPs within companies in the Malaysian manufacturing sector.

\section{LITERATURE REVIEW}

\section{The Miles and Snow Business Strategy}

Previous researchers had developed several theories to clearly describe and interpret strategic behaviors in organizations, such as Mintzberg (1987), Miles and Snow (1978), and Porter (1980). Besides that, it is also been shown by many researchers that the theories by Miller and Friesen (1982) and Gupta and Govindarajan (1984) are the most frequently used concepts in prior studies (cited in, Langfield-Smith, 1997). Furthermore, ever since the 1970s, there has been a growth in the number of business strategic typologies published by various researchers (Simons, 1990). However, these strategic typologies cannot perfectly distinguish the behavior of businesses because of business complexity and changeability; but, it fulfills the research purposes of predicting an organization's behavior based on the typologies used (Grasetti \& Bhimani, 2013).

Mintzberg (1987), with the "5Ps" theory, was introduced to develop strategy, comprising five significant steps: plan, ploy, pattern, position, and perspective. In developing an effective strategy, an organization must first plan its strategy of success with the structured plan, and then only continue with the deployment of action (Mintzberg, 1987). Another widely used theory as a reference for business strategy is the 'Generic Strategies' by Porter (1980). According to this theory, an organization may choose three generic strategies to attain competitive advantage, and those strategies are cost leadership, differentiation, or focus strategy (Porter, 1980). This theory 
also suggests that an organization that applies more than one strategy may have a higher success rate than an organization that only practices one generic strategy (Wright, Kroll, Kedia, \& Pringle, 1991).

Despite all the conceptual business strategy theories introduced, the Miles and Snow (1978) model of business typology was used in this study. This model was agreed upon and mostly referred to as the best approach by many researchers, mainly to interpret both sides of a firm's business and marketing strategy (Conant et al., 1990). The typology focused on the interaction between the organization and the environment and the change rate of a firm's products or market (Naranjo-Gil, 2004). This theory is also more practical to be used in understanding the relationship between organizational behavior with management accounting and risk management (Grasetti \& Bhimani, 2013). Theoretically, the businesses will create their own set of environments by utilizing business components such as markets, products, technologies, and operational scale as categorized by the typology proposed (Miles \& Snow, 1993).

The Miles and Snow (1978) business typology model is also considered the most suitable model to be used in research because it provides the complete description of organizational characteristics linked with those strategies compared to the other proposed behavioral concepts (Dent, 1990). Furthermore, the business typology model is also appropriate to assess the innovation of a management accounting system as the capacity of innovation of a firm stands as a dimension in this model (Gosselin, 1997). The business typology theory by Miles and Snow consists of four categories, precisely: defender, prospector, analyzer, and reactor (Barney \& Griffin, 1992).

\section{Defender}

The defender type of typology works as a defensive domain (Bustamam, 2011). Stability in the business environment and emphasis on the control to regain maximum efficiency are the nature of this type of firms. They also practice a high centralization control process with a narrow product market strategy (Miles \& Snow, 1993). This type of firms also imply fewer product innovations (Grasetti \& Bhimani, 2013). The defender types also seldom search for new market opportunities, and their main focus is to maintain the market by best serving their current customers (Miles \& 
Snow, 1993). Therefore, they do not replicate the example outside of their product-market domain in identifying new opportunities for their business (McDaniel \& Kolari, 1987). Apart from that, ensuring a high standard of quality, competitive pricing, excellent customer services, and emphasizing efficiency and cost control are critical elements on how defender firms sustain themselves in the market (Grasetti \& Bhimani, 2013). Besides, the defender type often offers a meager price for their limited product range compared to their competitor as a strategy to protect their market (Hambrick, 1983). Defender groups also carry out a very high level of marketing and market link capabilities as a means for them to achieve organizational goals (Conant et al., 1990).

\section{Prospector}

The prospector type tends to be dynamic and flexible to changes in the environment compared to the other categories of business typologies. This type of typology can combat challenges in their environment (Miles $\&$ Snow, 1978). It is also typical for the firm with a prospector behavior to find a new market or develop new products and, at the same time, have a balance between marketing technologies and management capabilities (Desarbo, Benedetto, Song, \& Sinha, 2005). Firms with prospector characteristics usually have more tolerance of business risks than the other types of typologies due to its natural behavior of encouraging risk-taking (Miles \& Snow, 1978). Prospector firms also usually perceived more environmental changes and uncertainties compared to the defender type of firms. It is also explained why their strategies are considered inherently riskier than the other types of business typologies (Tan \& Connor, 2001). Rapid technological changes are the markers for these types of firms. Some examples of the prospector firms are typically organizations in the medical care and biotechnology industries (Walker, Boyd, Mullins, \& Larreche, 2003). Besides that, operating in the dynamic product-market environment also implicates that the prospector firms be more adaptive (Grasetti \& Bhimani, 2013). Being a pioneer of bringing new ideas to the market, prospector firms also successfully accumulate a better profit margin than their competitors at a similar location due to their aggressive selling strategies (Hao, Weston, \& Tang, 2006). 


\section{Analyzer}

The analyzer type of firm, is considered as a hybrid typology. It is because this type of typology sustains the balance between the prospector and defender types of behavior. The analyzer type exploits new product and market opportunities simultaneously while focusing on maintaining its base product and customers (Miles \& Snow, 1978). The analyzer firms also have a moderate emphasis on both product and market innovations. They also change according to the necessary needs to maintain customer satisfaction (Miles \& Snow, 1978). They are known as the 'balanced players' in the industry, analyzer types of firms often improvise first-mover strategy for domestic and international markets. They tend to replicate the 'penetration' strategy by other organizations much better where it seems fit and profitable (Hao et al., 2006). Besides that, analyzer firms best represent the combination of both prospector and defender type strengths by introducing a limited number of cost-efficient products and only turn their focus from these products whenever there are viable opportunities to market a new one (Grasetti \& Bhimani, 2013).

\section{Reactor}

Firms within a reactor typology ineffectively respond to the changes in the business environment (Miles \& Snow, 1978). Other types of typologies usually outperform reactor-type firms because of a lack of appropriate response to the changes in the business environment (Desarbo et al., 2005). It is also considered an unsuccessful organizational type compared to the other typologies (Grasetti \& Bhimani, 2013). Firms with reactor characteristics often have no consistent strategy in operating a business. The organization with this type of typology is usually defined as an opportunist and only pursues specific projects throughout a period without distinction from their basic strategy (Hao et al., 2006). The reactor type firms are also considered very passive to the changes and rarely adjust unless they are forced to do so due to the pressures in the environment (Miles \& Snow, 1978). Reactor firms are passive in protecting their product-market domain and are typically intolerant in facing risks and uncertainties (Grasetti \& Bhimani, 2013). Sometimes, their behavior is surprised when they are very responsive to the short-term market demand, although they have no consistency in their strategic planning (Desarbo et al., 2005). However, empirical evidence 
which describes the reactor typology have shown mixed results (Cadez \& Guilding, 2009). Some researchers have agreed that the reactor typology firms were just the residual group of other typologies (Doty, Glick, \& Huber, 1993). In conjunction with that, Snow and Hrebiniak (1980) believed that reactor groups are only influential in a condition where the environment is highly regulated (Cadez \& Guilding, 2009).

\section{Management Accounting Practices}

Management accounting is an integral part of the management process because it provides essential information to control the current business operation and plan for the future through effective decision-making (IFAC, 1998). The importance of MAPs prevails when providing crucial feedback to managers. A firm can learn and gain information based on its current environment and utilize it to forecast the future (Atkinson et al., 1997). Thus MAPs play a role in building a compromise between institutional pressures and organizational change in strategic planning (Laguecira, Kernc, \& Kharoubid, 2020).

All business sectors, including the manufacturing industry, need to be more flexible and responsive to the changes in the business environment to remain competitive (Smith, Morris, \& Mahmoud, 2005). It is because the global competition has nurtured a kind of contemporary business environment that required firms to understand the determinants for prosperity, such as innovative management accounting techniques (Cescon, Costantini, \& Rossi, 2013). For manufacturing firms to achieve superior performance requires joint work from many fields to realize the objectives (Grasetti \& Bhimani, 2013). Globalization had also implicated the business environment of Malaysian manufacturing companies with an increased intensity in the level of competition, uncertainties or unexpected changes, and technological advancements (Tuanmat \& Smith, 2011). These may affect the changes in MAPs used by the companies in this sector. Management accounting is also the source of strategic decisions as it is the critical component for the manufacturing firms to successfully develop a manufacturing strategy (Fry, Steele, \& Saladin, 1995). Therefore, the role of MAPs is said to be an integral part of operations for manufacturing companies (Fry et al., 1995), and adopting MAPs will improve business sustainability (Azudin \& Mansor, 2018). 
On the other hand, the relationship between business strategy and MAPs cannot be taken lightly. MAPs affect all processes and change all systems in simple to complex systems (Shahzadi et al., 2018). For example, the business strategy also used MAPs to develop a strategic plan in the manufacturing industry (Tsamenyi, Sahadev, \& Qiao, 2011). The influence of business strategy on MAPs is also supported by other researchers, such as Gosselin (1997) and Anderson and Lanen (1999) that witnessed the influence of the prospector business typology with advanced MAPs.

\section{Business Strategy and Management Accounting}

Business strategy is the action blueprint which managers adopt in utilizing organizational resources to develop distinctive competencies to gain a competitive advantage over rivals in a market or industry (Hill $\&$ Jones, 2001). The choice of a strategy adopted by the firm defines the overall success or failure (Carroll, 1982). The business strategy applied in an organization depends on the relevant information within the organization itself to be fully useful (Abernethy \& Guthrie, 1994). With the meaningful information supplied, only strategic action derived from the business strategy can affect crucial organizational decisions such as account planning (Osler, 2003). Therefore, it is plausible to state that the choice of business strategy also will affect the management accounting information system of an organization (Ramli \& Iskandar, 2014).

A volatile economic environment at the macro and micro levels calls for the need to adopt more effective strategic management analysis in generating information and making proper managerial decisions, especially in economic transformation (Erokhin et al., 2019). Management accounting had witnessed linkages between management accounting and business strategy. Management accounting practices are usually tailored to be consistent with a firm's business strategy (Chenhall \& Langfield-Smith, 1998b). The linkages between the strategy of the business and management accounting practices can further be seen through the transitioning of strategic planning into the growth of accounting tools (Jack, 2013). Furthermore, some management accounting components, such as strategic management, were tested not loosely coupled with the business strategy (Cinquini \& Tenucci, 2010). The evidence is further supported by several studies which tested the relationship between the management accounting system and 
business strategy which deposited the same result since it regularly affects each other in developing strategic development (Tsamenyi et al., 2011). In order to achieve superior organizational performance, a management control system should always be tailored explicitly support the strategy of the business (Langfield-Smith, 1997). It is consistent with the idea that an interrelationship coexisted between management control and business strategies (Macintosh, 1994). With his study in 2007, Kober also supported the statement throughout his study when recognizing a passive relationship between the management accounting system and business strategy that complemented each other. In addition to that, the business strategy also carries a significant impact in nurturing the change of MAPs of a firm (Gosselin, 1997). This statement was also supported when the business strategy was recognized as the primary factor that internally drives a company's MAPs (Ahmad, 2012).

The possibility of the relationship between business strategies with management accounting can be further supported with the Contingency Theory (CT). The CT suggested that strategy is one of the contingencies affecting MAPs (Chenhall, 2003). With the influence of exogenous factors such as business strategy, the practice of management accounting can evolve, for example, from traditional into contemporary or advanced MAPs (Nimtrakoon \& Tayles, 2010). Different scopes of information supplied by the MAPs may also suit the strategy to be adopted accordingly. For example, the prospector strategy is usually associated with a broad range of information, affecting its performance (Abernethy \& Guthrie, 1994). The argument that suggests that the types of business strategy affects the MAPs when sophisticated Accounting Information System design is often related to the prospector strategy. It is also the mediating variable of a firm's performance strategy (Naranjo-Gil, 2004). It is consistent with the fact that for some firms, the information supplied by traditional management accounting is not sufficient to cope with its strategic needs and is considered counter-productive to its effective management decision-making (Otley, 2001). However, the situation is different with different typologies such as a defender, where the growth of the information scope of the management accounting is not substantial compared to the prospector strategy (Abernethy \& Guthrie, 1994). 
As previous studies had focussed less on the influence of the different business strategy typologies on the adoption of MAPs, this study aimed to investigate how the adoption of different typologies suggested by Miles and Snow (1978) affect the MAPs of an organization.

\section{Hypotheses}

There is evidence that companies with a prospector strategy has a stronger tendency to adopt advanced MAPs (Ramli \& Iskandar, 2014). On the other hand, firms with a defender strategy is perceived to have a slower change in the MAPs than the prospector. The defender type is relatively risk-averse compared to the prospector, and the information supplied by the traditional MAPs is considered sufficient (Abernethy \& Guthrie, 1994). Thus, it can be seen that MAPs depended on the amount and type of information needed for the business. Eventually, it will affect a firm's choice to either choose a traditional or advanced technique that fits the requirement. Therefore, the hypotheses that represent the first two typologies, namely, the defender and the prospector are:

H1: Companies with a defender type strategy will influence the adoption of MAPs.

H1a: Companies with a defender type strategy will influence the adoption of traditional MAPs.

H1b: Companies with a defender type strategy will influence the adoption of advanced MAPs.

H2: Companies with a prospector type strategy will influence the adoption of MAPs.

H2a: Companies with a prospector type strategy will influence the adoption of traditional MAPs.

H2b: Companies with a prospector type strategy will influence the adoption of advanced MAPs.

As for the analyzer and reactor types, there is not much evidence on how these strategies affect the MAPs. Therefore, researchers tend to focus more on the defender and prospector types since these two types were considered essential strategies (Grasetti \& Bhimani, 2013). However, in this study, the influence of these two types of typologies was investigated 
to set further evidence whether the analyzer and reactor typologies are also determinants for the adoption of MAPs. Therefore the hypotheses for the two typologies are :

H3: Companies with an analyzer type strategy will influence the adoption of MAPs.

H3a: Companies with an analyzer type strategy will influence the adoption of traditional MAPs.

H3b: Companies with an analyzer type strategy will influence the adoption of advanced MAPs.

H4: Companies with an analyzer type strategy will influence the adoption of MAPs.

H4a: Companies with an analyzer type strategy will influence the adoption of traditional MAPs.

H4b: Companies with an analyzer type strategy will influence the adoption of advanced MAPs

\section{METHODOLOGY}

The purposes of this study were first to identify the business strategy typology of manufacturing companies in Malaysia following the Miles and Snow (1978) typology. The business strategy typology had suggested that companies in the same category in the typology portrayed a similar business behavior within the group, which were identified as defender, prospector, analyzer, and reactor. The second purpose was to examine the adoption of management practices, traditional and advanced practices, and how the different business strategy typologies influenced them. Data for this study was collected using a questionnaire survey to 310 selected manufacturing companies throughout Malaysia. The manufacturing industry was chosen because the industry is often associated with management accounting practices such as ABC, JIT, and TQM (Smith, 2008). The manufacturing industry also tends to be exposed to more significant changes in the business environment than any other industry (Innes \& Mitchell, 1990), which provides a variety of typologies to be observed. 
The sample companies were randomly selected from the manufacturing companies registered with the Malaysia External Trade Development Corporation (MATRADE). There were 1,568 manufacturing companies registered as local manufacturers, which is the total number for the entire population for this study. In conjunction with that, a reliable sample size would be 310 companies according to the reliability tabulation by Krejcie Morgan (1970) to make the data reliable for analysis. Questionnaires were distributed through an online survey using Google form and e-mails to the respective managers in the finance department. Out of 310, 61 answered surveys were returned (20\%). The number of surveys collected was sufficient to be analyzed since a response rate of below $25 \%$ in management accounting research is considered normal (Baines \& Langfield-Smith, 2003).

The questionnaire consisted of three main parts: the demographic section, the organizational characteristics, and strategy, and organizational management accounting practices. The first part of the survey was on demographic information of the firms. There were five questions involved; industry classification, type of firm, products manufactured, number of employees, and years of establishment. The industry classification applied was derived from the category provided in the MATRADE list. Nonresponse bias was analyzed by comparing the mean of early responses (3.56) and late responses (3.52), which indicated a no response bias.

Typologies that the organization belonged to were categorized based on the characteristics portrayed by the answers from the respondents. As shown in Table 1 all the items for variable measurement were adopted from Miles and Snow (1993) based on the characteristics of the organizations with specific typologies, which were defender, prospector, analyzer, and reactor. Each item had four selections of answers which represents the characteristic of the typologies as suggested by Miles and Snow (1978). 
Table 1: Characteristics of Typologies

\begin{tabular}{|c|c|c|c|c|}
\hline Items & Prospector & Defender & Analyzer & Reactor \\
\hline $\begin{array}{l}\text { Organizational } \\
\text { structure }\end{array}$ & Divisional & Functional & Mix structure & Not clear \\
\hline Control process & Decentralized & Centralized & Mix structure & Not clear \\
\hline Dominant coalition & $R \& D$ & $\begin{array}{l}\text { Finance \& } \\
\text { Accounting }\end{array}$ & $\begin{array}{l}\text { Marketing } \\
\text { \& process } \\
\text { reengineer }\end{array}$ & Not clear \\
\hline Product line strategy & $\begin{array}{l}\text { Broad \& } \\
\text { changing }\end{array}$ & $\begin{array}{l}\text { Limited \& } \\
\text { stable }\end{array}$ & Flexible & Not clear \\
\hline Market condition & Changing & Predictable & Mix condition & Not clear \\
\hline $\begin{array}{l}\text { Research and } \\
\text { development }\end{array}$ & Extensive & Limited & Focused & Not clear \\
\hline Production volume & $\begin{array}{l}\text { Customize \& } \\
\text { prototype }\end{array}$ & $\begin{array}{l}\text { High volume } \\
\text { low cost }\end{array}$ & $\begin{array}{c}\text { Flexible } \\
\text { volume \& cost }\end{array}$ & Not clear \\
\hline $\begin{array}{l}\text { Production line } \\
\text { emphasis }\end{array}$ & Design & $\begin{array}{l}\text { Process } \\
\text { reengineer }\end{array}$ & Mix emphasis & Not clear \\
\hline Marketing strategy & Market research & Sales & Marketing & Not clear \\
\hline
\end{tabular}

In measuring the influence of the business typologies on MAPs, a 5 point Likert Scale was used, ranging from "used significantly less" to "used significantly more" with the other scale of "N/A" or not applicable at all in the organization. Fifteen items were used to measure the variable, adopted from Baines and Langfield-Smith (2003) and Tuanmat and Smith (2011). Those 15 items for the dependent variable were represented as follows:

Table 2: Measurements for MAPs

\begin{tabular}{ll}
\multicolumn{1}{c}{ Variables } & \multicolumn{1}{c}{ Scale/ Items } \\
\hline Traditional Management Accounting & - Budgetary control \\
Technique (TMAT) & - Full/absorption costing \\
& - CVP Analysis \\
& - Standard costing \\
& - Total Quality Management (TQM) \\
Advanced Management Accounting & - Target costing \\
Technique (AMAT) & - Activity-Based Costing (ABC) \\
& - Value chain analysis \\
& - Product life cycle analysis \\
& - Benchmarking \\
& - Product profitability analysis \\
& - Customer profitability analysis \\
& Shareholder value analysis/ EVA \\
\hline
\end{tabular}




\section{FINDINGS}

\section{Business Strategy Typologies}

Nine measurement items were used to determine the overall typology that belonged to a particular company.

Table 3: Business Strategy Typologies

\begin{tabular}{|c|c|c|c|c|c|c|c|c|c|c|}
\hline \multirow[b]{2}{*}{ Items } & \multicolumn{2}{|c|}{ Defender } & \multicolumn{2}{|c|}{ Prospector } & \multicolumn{2}{|c|}{ Analyzer } & \multicolumn{2}{|c|}{ Reactor } & \multicolumn{2}{|c|}{ Total } \\
\hline & $\mathbf{F}$ & $\%$ & $F$ & $\%$ & $F$ & $\%$ & $\mathbf{F}$ & $\%$ & $\mathbf{F}$ & $\%$ \\
\hline Orgn structure & 23 & 38 & 29 & 48 & 7 & 12 & 2 & 3 & 61 & 100 \\
\hline Control process & 34 & 56 & 19 & 31 & 8 & 13 & 0 & 0 & 61 & 100 \\
\hline $\begin{array}{l}\text { Important } \\
\text { Department }\end{array}$ & 24 & 39 & 12 & 20 & 22 & 36 & 3 & 5 & 61 & 100 \\
\hline Product line strategy & 32 & 52 & 7 & 12 & 19 & 31 & 3 & 5 & 61 & 100 \\
\hline Market environment & 15 & 25 & 6 & 10 & 40 & 66 & 0 & 0 & 61 & 100 \\
\hline R\&D intensity & 9 & 15 & 13 & 21 & 34 & 56 & 5 & 8 & 61 & 100 \\
\hline $\begin{array}{l}\text { Production volume } \\
\text { strategy }\end{array}$ & 18 & 30 & 10 & 16 & 31 & 51 & 2 & 3 & 61 & 100 \\
\hline $\begin{array}{l}\text { Production line } \\
\text { emphasis }\end{array}$ & 10 & 16 & 12 & 20 & 30 & 49 & 9 & 15 & 61 & 100 \\
\hline Marketing strategy & 35 & 57 & 9 & 15 & 11 & 18 & 6 & 10 & 61 & 100 \\
\hline Average Frequency & \multicolumn{2}{|c|}{22} & \multicolumn{2}{|c|}{13} & \multicolumn{2}{|c|}{23} & \multicolumn{2}{|c|}{3} & \multicolumn{2}{|c|}{61} \\
\hline Mode & \multicolumn{2}{|c|}{23} & \multicolumn{2}{|c|}{16} & \multicolumn{2}{|c|}{20} & \multicolumn{2}{|c|}{2} & & \\
\hline
\end{tabular}

The analyzer-type business strategy was the most dominant typology (frequency $=23$ ) among the 61 samples collected, followed by the defender (frequency $=22)$, prospector $($ frequency $=13$ ), and reactor $($ frequency $=3$ ). The result of the average score for each typology was in the expected range. Thus, the defender and analyzer types scored the highest mode compared to the prospector and reactor types.

The result showed that $48 \%$ of the companies were categorized as the prospector-type for their organizational structure compared to the other types. It means that the divisional organizational structure was favored by Malaysian manufacturing companies. On the other hand, the defender type was widely used among firms in terms of the element of the control process, important departments, product line strategies, and marketing strategies. It means that most of the firms in the Malaysian manufacturing industry 
operated a centralized control process by utilizing the finance and accounting departments as the most critical coalition, focusing on broad and changing production lines and primarily focusing on sales as the marketing strategy. The result also showed that the element of market environment, research and development intensity, production volume strategy, and the emphasis of the production line were influenced predominantly by the analyzer type compared to the other typologies. This study also found that most of the firms from the sample operated in a market condition that was sometimes predictable and changeable. The result also indicated that most of the firms utilized focus intensity in the research and development strategy. the distribution of typology is summarized in Figure 1.

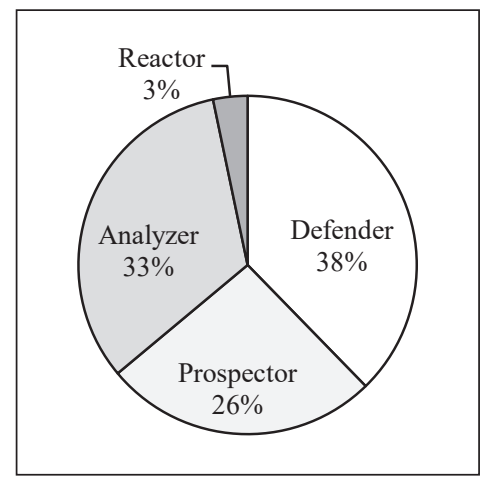

Figure 1: Distribution of Typologies

Most of the sample companies in the Malaysian manufacturing industry possessed the characteristic of a defender typology. This type of typology shows the highest frequency, which is 23 companies (38\%). The analyzer type was in second place, with 20 companies representing $33 \%$ of the total companies. The prospector type was in third place with a frequency of 16 companies or $26 \%$ out of the total respondents. The remaining number of companies belonged to the last typology: the reactor with only two companies out of 61 the total companies (3\%).

The result for the distribution of business strategy typologies among the sample companies can be explained by the establishment age of the sample companies. With reference to the result in the demographic analysis, about $89 \%$ of the sample which participated in this study were categorized as the medium-aged and mature companies. There were 23 companies labeled 
as medium-aged since their establishment was in the range of 5 to 20 years. In comparison, 31 companies were considered mature businesses as the establishment was for more than 20 years. Therefore, it can be assumed that many long-established companies were involved in the survey, which made it plausible to accept that the most frequent typologies adopted were the defender type. Consistent with Miles and Snow (1993), the older firm tended to have the defender strategy to achieve stability in the business environment and sustain continuous market demand.

The result in the demographic analysis was consistent with this assumption, as $87 \%$ of the samples in this study were considered medium and large firms. Significant human resources are often associated with the prospector type of firms that utilize a bigger workforce to cope with business demand. Also, considerable capital is required to finance a flexible typology such as the analyzer, which characterizes both the defender and prospector elements (Miles \& Snow, 1993).

The least frequent among all typologies recorded was the reactor-type (only two companies categorized in this type). The reactor-type can be considered the most unsuccessful typology (Grasetti \& Bhimani, 2013). It also possessed inconsistent business strategies compared to other typologies with a specific strategy pattern (Hao et al., 2006). It showed that most of the companies in the Malaysian manufacturing industry had their way of strategizing their business which enabled them to fall under specific categories of typologies other than the reactor type. Another characteristic of the reactor-type of business strategy, such as lack of response to the changes in the business environment, may also implicate that most of the firms in the Malaysian manufacturing industry opted not to practice this type of typology. There are possibilities that the low number of frequencies recorded from the reactor group may be due to the limitation of the number of samples.

\section{Management Accounting Practices}

Table 4 shows the descriptive result of the dependent variable, i.e., MAPs used in the manufacturing companies in Malaysia. There were 15 items for MAPs that were used to assess the intensity of its usage. The MAPs items were then divided into Traditional and Advanced MAPs to 
analyze further the different potential effects of the independent variables on MAPs. The asterisk mark on some of the practices denoted the traditional MAPs. Next, the mean score of each MAP was analyzed to identify the level of MAPs among the companies. The closest mean score to 5 indicated that the practice was extensively used within the organization. The rankings represented the mean scores for the practice in a descending order according to the most extensively used MAPs among firms in the Malaysian manufacturing industry to the least used within the organization.

For the traditional MAPs, standard costing was ranked first (mean = $3.90)$, followed by marginal costing (mean $=3.75$ ). Budgetary control was ranked third with a mean difference of only 0.01 from marginal costing. However, there was a significant gap between these three practices. The remaining two practices fell under the traditional MAPs, whereby CVP analysis and absorption costing scored the lowest mean of 3.34 and 3.25, respectively. Overall, it can be concluded that the companies highly used traditional MAPs since all practices had a mean score of more than 3 .

As for the advanced MAPs, total quality management (TQM) scored the highest mean (4.23). Product profitability analysis, target costing, and customer profitability analysis clustered in the second-highest mean scores for advanced MAPs with a mean of 4.02, 3.61, and 3.44, respectively. Shareholder value analysis, value chain analysis, and product life cycle analysis had a mean score of 3.44, 3.41, and 3.36, respectively. The result also showed that $\mathrm{ABC}$, benchmarking, and $\mathrm{ABM}$ scored the lowest mean in the category, and it can be concluded that these practices were used less in the sample firms.

Table 4: Descriptive Statistics for Overall MAPs

\begin{tabular}{lccc}
\hline \multicolumn{1}{c}{ MAPs } & Mean & SD & Rank \\
\hline Total Quality Management (TQM) & 4.23 & 0.80 & 1 \\
\hline Product profitability analysis & 4.02 & 3.90 & 2 \\
\hline Standard Costing* $^{*}$ & 3.90 & 0.94 & 3 \\
\hline Variable/ Marginal Costing* $^{*}$ & 3.75 & 1.14 & 4 \\
\hline Budgetary control $^{*}$ & 3.74 & 0.87 & 5 \\
\hline Target costing $^{\text {Customer profitability analysis }}$ & 3.61 & 5.36 & 6 \\
\hline
\end{tabular}




\begin{tabular}{llll}
\hline Shareholder value analysis & 3.44 & 1.01 & 8 \\
\hline Value chain analysis & 3.41 & 1.02 & 9 \\
\hline Product life cycle analysis & 3.36 & 1.15 & 10 \\
\hline Cost volume profit analysis (CVP)* & 3.34 & 1.31 & 11 \\
\hline Activity based costing (ABC) & 3.26 & 1.14 & 12 \\
\hline Full/ Absorption costing & 3.25 & 1.13 & 13 \\
\hline Benchmarking & 3.20 & 1.06 & 14 \\
\hline Activity based management (ABM) & 3.18 & 1.18 & 15 \\
\hline $\begin{array}{l}\text { TOTAL MEAN } \\
\text { Cronbach's alpha = } \mathbf{0 . 8 9 2} \\
\mathbf{N}=61\end{array}$ & 3.54 & & \\
\hline${ }^{*}$ Traditional MAPs & & & \\
\hline
\end{tabular}

TQM was the most highly used MAPs in Malaysian manufacturing companies. It might be due to the customer's inevitable demand for quality products nowadays, which caused firms in the manufacturing sector to channel their attention to financial and non-financial information in their operations, which are addressed in TQM. Standard costing, marginal costing, and budgetary control scored the highest ranking after TQM, and the result showed that these traditional practices were somehow more important than the other advanced practices. This finding provides evidence that these traditional MAPs are still relevant in the Malaysian manufacturing business environment, in addition to the advanced MAPs. This result is consistent with Tuanmat and Smith (2011). The uprising of advanced MAPs can be seen in this study. Most firms used the practices extensively, such as product profitability analysis, customer profitability analysis, shareholder value analysis, value chain analysis, and product life cycle analysis. The result strongly supports the statement that most of these practices obtained a mean score of more than 3.4, which meant that it was widely used within the organizations.

Target costing was also one of the favorable advanced MAPs used in the manufacturing companies in Malaysia. With a mean score of 3.61, it can be considered that the usage was above average. These results are supported by Sulaiman et al. (2004), which forecasted that the MAPs in companies involving target costing will increase consistent with the exposure of firms to advanced MAPs from time to time. The result showed that ABM recorded the lowest mean in all of the 15 MAPs assessed. The usage of 
$\mathrm{ABM}$ in themanufacturing firms in Malaysia can be said to be moderate since the mean barely passed the 3.0 mark by 0.18 . However, the result may vary due to some challenges in implementing it, such as the sophistication of the techniques, lack of expertise, limited funding, and perhaps lack of top management support (Sulaiman et al., 2004). ABC and benchmarking recorded a slightly higher mean than $\mathrm{ABM}$, which showed that they are moderately used in manufacturing firms in Malaysia.

The advanced practice scored the highest mean, but at the same time, three types of traditional MAPs followed closely with a slight difference in the mean. Most companies, including small and medium-sized companies, showed a strong interest in advanced MAPs (Alvarez et al., 2021). Therefore, it can be concluded that both of the techniques somehow need to work together, or in other words, complements each other (Baines \& LangfieldSmith, 2003). The total mean for all the MAPs showed a high level of usage of MAPs in the firms in the Malaysian manufacturing industry (mean=3.54). The result is consistent with Chenhall and Langfield-Smith (1998a), where both traditional and advanced MAPs were essential to a firm's operational needs and the level of practice for both techniques was consistent with Yusuff (2004) and (Tuanmat \& Smith, 2011).Furthermore, Nair and Yee (2017) found that companies that used advanced production technology significantly correlated with MAPs. Usage of MAPs is more prevalent in the manufacturing sector than in the service sector. This finding is supported by Nagirikandalage et al. (2020), who found that the usage of MAPs was more prevalent in the manufacturing industry than in the service sector, and the traditional and advanced MAPs were being used concurrently.

\section{Validity and Reliability}

Before proceeding to regression analysis, a preliminary test was carried out. Normality, reliability, validity, and multicollinearity tests were conducted, and all assumptions of the analysis were met. The measures of the variables met the face validity requirement as they were adopted from previous studies. The independent variables for this study were categorical variables. Thus, it was sufficient to use mode frequency and correlation matrix (which is the basis for alpha) to measure internal reliability for the categorical variables, equivalent to a phi coefficient (Bhandari, 2020; Zapf, 2016). Since the variables were normally distributed, the variables 
were considered reliable. The Cronbach's alpha for the dependent variable, MAPs, was recorded at 0.892 . It showed that the scale used in this study was reliable since it was more than the threshold value of 0.7 (Table 4).

Table 5: Correlation Matrix

\begin{tabular}{lllllll}
\hline & Trad MAPs & Adv MAPs & MAPs & DEF & PROS & ANAL \\
\hline Trad MAPs & 1 & & & & & \\
\hline Adv MAPs & -0.43 & 1 & & & & \\
\hline MAPs & -0.03 & $0.91^{* *}$ & 1 & & & \\
\hline DEF & $0.59^{* *}$ & $-0.64^{* *}$ & $-0.45^{* *}$ & 1 & & \\
\hline PROS & $-0.78^{* *}$ & $0.53^{* *}$ & 0.23 & $-0.46^{* *}$ & 1 & \\
\hline ANAL & 0.18 & 0.19 & $0.30^{*}$ & $-0.54^{* *}$ & $-0.42^{* *}$ & 1 \\
\hline
\end{tabular}

${ }^{*}$ Correlation is significant at the 0.05 level (2-tailed)

${ }^{* *}$ Correlation is significant at the 0.01 level (2-tailed)

Table 5 indicates the correlation between all of the main variables in this study. The recorded correlation between the defender and the prospector types was -0.46 . Two variables with a bivariate correlation of 0.7 or more in the same analysis should not be included (Pallant, 2011). The correlation values for the defender and analyzer; defender and reactor were -0.54 and -0.14 , respectively. The other values among the independent variables were not too high. They did not exceed 0.7 , except for the correlation between the prospector (PROS) and Traditional MAPs, which was -0.78 , which was slightly above the 0.7 threshold value. Additional examination on the multicollinearity was analyzed using the VIF and Tolerance. Correlation between MAPs and Advanced MAPs of 0.90 was not considered for multicollinearity issues as the Advanced MAPs were part of overall MAPs. Furthermore, the relationship between these variables was not tested in the regression analysis as it was also not part of the hypothesis.

The level of multicollinearity was further assessed using the $V I F$ and tolerance. The recorded tolerance and VIF values for all variables were in the range. The value for tolerance was more than 0.1 , and the value for VIF was below 10. This result indicated that all of the variables could be retained as the was no multicollinearity issue. 


\section{Influence of Business Strategy Typologies on MAPs}

Regression analysis was performed to examine the influence of the business strategy typologies on adopting MAPs among firms in the Malaysian manufacturing industry. The reactor type of business typology was excluded for this analysis due to the small number of companies categorized under this typology (two companies).

The correlation resulted in a significant value for the defender typology with the traditional also advanced MAPs (Table 5). The result also traced a significant correlation on the prospector typology as well on both types of MAPs. For the defender type, the correlation showed a strong positive relationship (0.59) with the traditional MAPs while a robust negative relationship (-0.64) with advanced MAPs. For the prospector typology, a strong positive relationship (0.53) with the advanced MAPs was recorded, while for the traditional MAPs showed an opposite result with a strong negative relationship (-0.78). The result from the correlation analysis was consistent with Ramli and Iskandar (2014) that evidenced a dynamic adoption of sophisticated MAPs among the prospector type firms compared to the defender type firms.

Table 6: Regression Results

\begin{tabular}{lccccccccc} 
& \multicolumn{3}{c}{ Trad MAPs } & \multicolumn{3}{c}{ Adv MAPs } & \multicolumn{3}{c}{ MAPs } \\
\cline { 2 - 10 } & Beta & $\mathbf{t}$ & Sig. & Beta & $\mathbf{t}$ & Sig. & Beta & T & Sig. \\
\hline DEF & 0.82 & 4.18 & 0.00 & 0.21 & -0.80 & 0.43 & 0.13 & 0.42 & 0.68 \\
\hline PROS & -0.16 & -0.92 & 0.36 & 0.56 & 2.31 & 0.03 & 0.55 & 1.85 & 0.07 \\
\hline ANAL & 0.55 & 2.92 & 0.00 & 0.32 & 1.24 & 0.22 & 0.60 & 1.93 & 0.05 \\
\hline $\mathbf{R}^{\mathbf{2}}$ & 0.72 & & & 0.49 & & & 0.25 & & \\
\hline Adj $^{\mathbf{2}}$ & 0.70 & & & 0.47 & & & 0.21 & & \\
\hline
\end{tabular}

The results as in Table 6 explain the influence of the typologies on MAPs for the traditional, advanced, and MAPs. The result for the defender and MAPS showed that the beta for regression was weak and not significant. The significance value was at 0.68 where $p>0.05$. The result showed a strong positive influence for the defender type and traditional MAPs, with a beta value of 0.82 . It was also supported with a significance value of $0.000(p<0.01)$. Based on the result, the defender typology had a positive 
influence on firms adopting traditional MAPs. This result is consistent with Cinquini and Tenucci (2010) that evidenced that the element of the costcontrol that existed in the traditional MAPs has become the main reason why this practice is prevalent among defender type companies. The influence of the defender typology on the advanced MAPs could not be determined since the regression result was not significant (0.43), even though the beta showed an inverse relationship (-0.211) between this typology and MAPs.

There was a strong positive relationship between the prospector type with the overall MAPs with a beta value of 0.546 . However, the result was not significant $(p>0.05)$. The result also showed a negative relationship between this typology and traditional MAPs with a beta value of -0.17 . However, this relationship was too weak and not significant (beta value is $0.36 ; p>0.05$ ). The result showed a significant influence of the prospector type on the adoption of advanced MAPs. The result showed a strong positive beta (0.56) which explained that the firms with this typology are influenced to adopt the advanced MAPs in their operations. This result is consistent with Abernethy and Guthrie (1994), which stated that the extensive information provided by the advanced MAPs would influence the extent of its use among prospector type companies.

The result on the influence of the analyzer type on MAPS showed a strong positive relationship based on the beta value. However, the result was not supported as $p>0.05$, with a slight difference in the significance value at 0.06 . However, the result showed that this typology had a strong positive relationship with traditional MAPs. The beta value (0.56) explained that the analyzer type could influence firms to use traditional MAPs. On the other hand, the influence of the analyzer on the adoption of advanced MAPs was not significant (0.22), where $p>0.05$. This result might be because most analyzer type of companies are long-established companies. A long-established company is usually associated with significant capital and human labour (Miles \& Snow, 1993). Therefore, in the Malaysian manufacturing environment context, the analyzer type tends to be more towards the characteristic of a defender typology and indirectly adopt the same preference of MAPs than the traditional MAPs rather than the advanced MAPs. 
Overall, the result from the analysis of this study simplified the three main typologies widely used among Malaysian manufacturing firms: defender, prospector, and analyzer. The reactor typology showed a minimal frequency, therefore the data was not analysed further or regressed to test its relationship with the MAPs due to the bias from the number of samples and the high probability of the presence of outliers. The result also showed that MAPs usage in the Malaysian manufacturing industry was high, where both traditional and advanced practices were vital in providing information to managers. The regression analysis showed that the typologies did not hypothetically influence the MAPs overall. However, the result was different when the MAPs were assessed differently, i.e., traditional and advanced MAPs. The results showed that in the manufacturing companies in Malaysia, the defender and the analyzer types tend to use traditional MAPs. In contrast, the prospector types used more advanced MAPs.

\section{DISCUSSION AND CONCLUSION}

This study identified the different typologies of business strategies used in Malaysian manufacturing companies. The result concluded that all four categories of business typologies existed in the Malaysian manufacturing industry. In conclusion, most manufacturing companies in Malaysia used the defender type of business strategy, followed by the analyzer and prospector types. However, a small number of companies being categorized as the reactor type might be due to the low response rate and the short data collection period.

This finding is consistent with studies by Miles and Snow (1993) and Cescon et al. (2013), which found that defender and prospector types were commonly used in organizations due to their consistency in strategies. The analyzer type was also favored in stable organizations since it offers a balance between a defender and a prospector typology (Hao et al., 2006; Miles \& Snow, 1993). These three types of business typologies (defender, prospector, and analyzer) also regularly outperformed the reactor typology in the effectiveness of the strategic plans, which made the reactor typology of business strategy least adopted by most organizations (Desarbo et al., 2005). 
This study also identified the level of MAPs in Malaysian manufacturing companies. The descriptive analysis on the MAPs evidenced that the Malaysian manufacturing industry highly adopted the MAPs. It is also consistent with the study by Tuanmat and Smith (2011) and Sulaiman et al. (2004), where both evidenced the improvement in the extent of use of MAPs, especially the advanced MAPs. Azudin and Mansor (2018) found that the adoption of MAPs would improve business sustainability. MAPs were also widely adopted in the manufacturing sector, with both traditional and advanced MAPs used concurrently (Nagirikandalage et al., 2020)

This study also examined the influence of the three typologies (defender, prospector, and analyzer) on MAPs. However, the result showed an insignificant relationship between all typologies with MAPs. It is consistent with prior research such as Abdul Kader and Luther (2008). However, the defender type had a significant influence on traditional MAPs. Cinquini and Tenucci (2010) observed that traditional MAPs are favored among the defender types since it provides just sufficient information for managers regarding efficiency and cost control. The result also showed that the defender typology tends not to influence the companies to adopt advanced MAPs.

However, it is different for the prospector typology, where the result showed that this typology influences the adoption of advanced MAPs in manufacturing companies in Malaysia. Chenhall (2003) suggested that the prospector strategy often leads companies to adopt sophisticated management accounting. The result also showed that the analyzer type in Malaysian manufacturing firms tend to choose traditional MAPs rather than advanced MAPs. The adoption of MAPs for analyzers can also contribute to this study as there was limited evidence on this typology.

This study contributes to the area of management accounting precisely. The results showed the possibility of the influence from the business typologies in the specific type of MAPs. The result is consistent with previous research and the business typologies theory by Miles and Snow (1978). Both academicians and practitioners of management accounting will notice that a firm's strategy will influence the types of MAPs used. This research area could be explored more by academicians in the future with more refined methodologies to provide more meaningful information. The 
manufacturing industry in Malaysia also may use the information that the level of usage of MAPs which were still at the moderate stage.

In future, the application of MAPs associating with the more sophisticated techniques should be constantly expanded among firms. This information is also vital for the government to take the opportunity to expose local manufacturers to more advanced techniques in the future to cope with the challenges of globalization and stimulate more competition in this industry and also taking into consideration the current development of digital technology.

A low response rate is a limitation of this study. The companies that responded in this research did not fully portray the population of the manufacturing industry in Malaysia. Thus, the result must be carefully generalized. It also might be the reason for only two samples obtained for the reactor business typology. The second issue in conducting this study is limited prior studies. There is a lack of previous research regarding business typologies in Malaysia. Therefore, the limitation existed in terms of the literature referencing preliminary studies related to typologies and MAPs, especially in the analyzer and reactor type of business typology that was rarely tested. Therefore, the result is mainly replicated from the studies carried out in foreign countries that might have different characteristics in the manufacturing environment compared to Malaysia. Thus, the justification of the result cannot be fully testified with solid evidence from previous researches. However, this limitation can also contribute to this study by contributing additional knowledge in management accounting and business strategy typology literature.

\section{ACKNOWLEDGMENT}

The authors would like to express their gratitude to the Faculty of Accountancy, Universiti Teknologi MARA for funding and facilitating this research project. 


\section{REFERENCES}

Abdul Kader, M., \& Luther, R. (2008). The impact of firm characteristics on management accounting practices: A UK-based empirical analysis. The British Accounting Review, 37(3), 261-297.

Abernethy, M. A., \& Guthrie, C. H. (1994). An empirical assessment of the "fits" between strategy and management information system design. Accounting and Finance, 34(2), 49-66.

Ahmad, K. (2012). Factors explaining the extent of use of management accounting practices in Malaysia medium firms. In Asian Entrepreneurship Conference 2012.

Alvarez, P., Sensini, L., Bello, C., \& Vazquez, M. (2021). Management Accounting Practices and Performance of SMEs in the Hotel Industry: Evidence from an emerging economy. International Journal of Business and Social Science, 12, 2, 24-35. https://doi:10.30845/ijbss.v12n2p3

Anderson, S. W., \& Lanen, W. N. (1999). Economic transition, strategy and the evolution of management accounting practices: The case of India. Accounting, Organizations and Society, 24(1), 379-412.

Atkinson, A. A., Balakrishnan, R., Booth, P., \& Cote, J. M. (1997). New directions in management accounting research. Journal of Management Accounting Research, 9(1), 79-108.

Auzair, S. M., Amiruddin, R., Majid, A. A., \& Maelah, R. (2013). Linking business strategy to management accounting: A study in Malaysian service organizations. Management Journal, 37(1), 45-52.

Azudin, A., \& Mansor, N. (2018). Management accounting practices of SMEs: The impact of organizational DNA, business potential and operational technology. Asia Pacific Management Review, 23(3), 222226.

Baines, A., \& Langfield-Smith, K. (2003). Antecedents to management accounting change: A structural equation approach. Accounting, Organizations and Society, 28(7), 675-698. 
Barney, J. B., \& Griffin, R. G. (1992). The management of organizations: Strategy, structure, behavior. Houghton Mifflin College Div.

Bhandari, P. (2020, August 12). Ordinal data: Examples, collection, and analysis. Retrieved from https://www.scribbr.com/statistics/ordinaldata/

Cadez, S., \& Guilding, C. (2009). Organizational configurations of strategic choices and strategic management accounting. Barcelona, Spain: Universitat Autònoma de Barcelona, 1 - 35.

Carroll, P. J. (1982). The link between performance and strategy. Journal of Business Strategy, 2(4), 3-20.

Cescon, F., Costantini, A., \& Rossi, G. (2013). The influence of business strategy and ownership on management accounting innovations and risk management techniques: an empirical analysis in large manufacturing companies in Italy. (D. o. E. a. Statistics, Trans.), Udine, Italy: Universita di Udine.

Chenhall, R. (2003). Management control system design within its original context: Findings from contingency-based research and directions for the future. Accounting, Organizations and Society, 28(1), 127-168.

Chenhall, R., \& Langfield-Smith, K. (1998a). Factors influencing the role of management accounting in the development of performance measures within organizational change programs. Management Accounting Research, 9(4), 361-386.

Chenhall, R., \& Langfield-Smith, K. (1998b). The relationship between strategic priorities, management techniques, and management accounting: An empirical investigation using a systems approach. Accounting, Organizations and Society, 23(3), 243-264.

Cinquini, L., \& Tenucci, A. (2010). Strategic management accounting and business strategy: A loose coupling? Journal of Accounting \& Organizational Change, 6(2), 228 - 259. 
Conant, J. S., Mokwa, M. P., \& Varadarajan, P. R. (1990). Strategic types, distinctive marketing competencies and organizational performance: A multiple measures-based studies. Strategic Management Journal, 11(5), 365-383.

Desarbo, W. S., Benedetto, C. A. D., Song, M., \& Sinha, I. (2005). Revisiting the Miles and Snow strategic framework: Uncovering interrelationships between strategy types, capabilities, environmental uncertainty, and firm performance. Strategic Management Journal, 26(1), 47-74.

Doty, D. H., Glick, W. H., \& Huber, G. P. (1993). Fit, equifinality and organizational effectiveness: A test of two configurational theories. Academy of Management Journal, 36(6), 1196-1250.

Erokhin, V., Endovitsky, D., Bobryshev, A., Kulagina, N., \& Ivolga, A. (2019). Management accounting change as a sustainable economic development strategy during pre-recession and recession periods: Evidence from Russia. Sustainability, 11(11), 1-23. https://doi. org/10.3390/su11113139

Fry, D, T., Steele, C, D., \& Saladin, A, B. (1995). The role of management accounting the development of a manufacturing strategy. International Journal of Operations \& Production Management, 15(12), 831-858.

Gosselin, M. (1997). The effect of strategy and organizational structure on the adoption and implementation of activity-based costing. Accounting, Organizations and Society, 22(2), 105-122.

Grasetti, L., \& Bhimani, A. (2013). The influence of business strategies and ownership on management accounting innovations and risk management techniques: An empirical analysis in large manufacturing companies in Italy. Milan, Italy.

Hambrick, D. (1983). Some tests of the effectiveness and functional attributes of Miles and Snow's strategic types. Academy of Management Journal, 26(1), 5-26. 
Hao, T., Weston, R., \& Tang, Y. (2006). Applying Miles and Snow's business strategy typology to China's real estate development industry: A research framework (Dissertation, Macquarie University).

Hill, C. W. L., \& Jones, G. R. (2001). Strategic management theory. Houghton-Mifflin Company, Boston, Massachusetts.

IFAC, I. F. o. A. (1998). International Management Accounting Practice Standard: Management accounting concepts.

Ilias, A., Razak, M. Z. A., \& Yasoa', M. R. (2010). The preliminary study of management accounting practices (MAPs) in small business. Global Business and Management Research: An International Journal, 2(1), 79-88.

Jack, D. L. (2013). The Adoption of strategic management accounting tools in agriculture post-subsidy reform: A comparative study of practices in the UK, the US, Australia, and New Zealand. Research Executive Summaries Series, 5, Chartered Institute of Management Accountants.

Kaplan, R. S., \& Norton, D. P. (1992). The balanced scorecard-measures that drive performance. Harvard Business Review, January, 71-79.

Laguecira, A., Kernc, A., \& Kharoubid, C. (2020). Management accounting systems in institutional complexity: Hysteresis and boundaries of practices in social housing. Management Accounting Research, 49 (December), 1-14.

Langfield-Smith, K. (1997). Management control systems and strategy: A critical review. Accounting, Organizations and Society, 22(2), 207-232.

Macintosh, N. B. (1994). Management accounting and control systems: An organizational and behavioral approach. John Wiley \& Sons.

McDaniel, S., \& Kolari, J. (1987). Marketing strategy implications of the Miles and Snow typology. Journal of Marketing, 51(4), 19-30.

Miles, R. E., \& Snow, C. C. (1978). Organizational strategy, structure, and process. McGraw-Hill Book Co, New York. 
Miles, R. E., \& Snow, C. C. (1993). Designing strategic human resource systems. Organizational Dynamics, 13(1), 36-52.

Mintzberg, H. (1987). The strategy concept 1: Five Ps for strategy. California Management Review, 30(1), 1-24.

Nagirikandalage, P., Binsardi, B., Kooli, K., \& Pham, A. N. (2020). The resistance in management accounting practices towards a neoliberal economy. Accounting, Auditing \& Accountability Journal, 34(3), 616650. https://doi.org/10.1108/AAAJ-12-2018-3793

Nair, S., \& Yee, S. N. (2017). Factors affecting management accounting practices in Malaysia, International Journal of Business and Management, 12(10), 177-184. https://doi.org/10.5539/ijbm. v12n10p177

Naranjo-Gil, D. (2004). The role of a sophisticated accounting system in strategic management. The International Journal of Digital Accounting Research, 4(8), 125-144.

Nimtrakoon, S., \& Tayles, M. E. (2010). Contingency factors of management accounting practices in Thailand: A selection approach. Asian Journal of Accounting and Governance, 1, 51-78.

Osler, R. (2003). Infusing business and brand strategies into account planning. Marketing Intelligence \& Planning, 21(7), 435-439.

Otley, D. (2001). Extending the boundaries of management accounting research: Developing system for performance management. The British Accounting Review, 33, 243-261.

Pallant, J. (2011). SPSS Survival Manual. McGraw Hill, England.

Porter, M. E. (1980). Competitive Strategy. Press release.

Ramli, I., \& Iskandar, D. (2014). Control authority, business strategy, and the characteristics of management accounting information systems. Procedia-Social and Behavioral Sciences, 164, 384-390. 
Shahzadi, S., Khan, R., Toor, M., \& Haq, A. U. (2018). Impact of external and internal factors on management accounting practices: a study of Pakistan, Asian Journal of Accounting Research, 3(2), 211-223. https:// doi.org/10.1108/AJAR-08-2018-0023

Simon, C. (2008). Strategy and strategic management accounting: An Investigation of organizational configurations. Paper presented at the Manchester Business School Research Seminar, Manchester, England.

Simons, R. (1990). The role of management control system in creating competitive advantage: New perspective. Accounting, Organizations and Society, 15(1-2), 127-143.

Smith, J., Morris, J., \& Mahmoud, E. (2005). Organizational change, outsourcing, and the impact on management accounting. The British Accounting Review, 374, 415-441.

Sulaiman, M., Nazli, N., \& Alwi, N. (2004). Management accounting practices in selected Asian countries: A review of the literature. Managerial Auditing Journal, 19(4), 493-508.

Tan, Y. L., \& Connor, N. (2001). A strategic response to a volatile environment: the case of cross-cultural cooperative ventures. Asia Pacific Journal of Management, 18, 7-25.

Tuanmat, T. Z., \& Smith, M. (2011). Changes in management accounting practices in Malaysia. Asian Review of Accounting, 19(3), 22 -242.

Walker, O., Boyd, H., Mullins, J., \& Larreche, J. (2003). Marketing strategy: Planning and implementation. Homewood, IL: Irwin/McGraw Hill.

Wright, P., Kroll, M., Kedia, B., \& Pringle, C. (1991). Strategic profiles and performance: An empirical test of select key propositions. Journal of the Academy of Marketing Science, 19, 245-254.

Yusuff, R. M. (2004). Manufacturing best practices of the electric and electronic firms in Malaysia. Benchmarking: An International Journal, 11(4), $361-339$. 
Zapf, A., Castell, S., Morawietz, L., \& Karch, A. (2016). Measuring interrater reliability for nominal data - Which coefficients and confidence intervals are appropriate? BMC Medical Research Methodology, 16, 93, https://doi.org/10.1186/s12874-016-0200-9 